\title{
The Implementation Of Education Concept $2+1$ And Estabishing The Professionalism Of Graduates Polytechnic LP3I Bandung
}

\author{
Iin Kurniawati, Yuyun Taufik \\ Politeknik LP3I Bandung, J1. Pahlawan No.59 Bandung 40123, Indonesia \\ Politeknik LP3I Bandung, Jl. Pahlawan No.59 Bandung 40123, Indonesia \\ iin.kw.saja@gmail.com, yoenta_72@yahoo.com
}

\begin{abstract}
The purpose of this study was to determine the extent of application of the concept of education $2+1$ and the formation of life in the form of soft skills professionalism and hard skills of graduates (exit study) LP3I Bandung Polytechnic year 2011.Using descriptive qualitative research methods, the instrument uses the data is purposive sampling questioner. The source of student graduation class of 2011 that followed the year 2014. The valid data source that filled the questionnaire as many as 159 alumni. Through this research are expected to find the relationship between the concept of $2+1$ through the domain of soft skills (curriculum) with the domain professionalism hard skills (competence work) can be accepted in the working directly before the graduation. The results show the alumni are satisfied in getting job, the work is suitable with the skill, it means has created the professionalism, the capability of $C$ and $P$ in helping the alumni is quite enough with the expectation of alumni in order to get a job. The alumni has enough skill and knowledge to apply the $2+1$ Concept. This study as an early stage and can be developed into useful for further research Polytechnic LP3I Bandung in particular and education in general and also the enrichment of the concept of education.
\end{abstract}

Keywords: education concept $2+1$, professionalism, soft skills, hard skills

\section{Introduction}

\subsection{Background}

Polytechnic LP3I Bandung is one of Higher Education Diploma program, has a concept of education $2+1$ (two plus one) is 2 (two) means an intensive study for 2 years, 1 (one) in the process of conducting internships and employment. For this reason Polytechnic LP3I Bandung facilitates students in addition to the existing curriculum materials but also the preparation of job competencies, such as: the practice table manners, beauty and handsome class, Achievement Motivation Training (AMT) which invited speakers from the business world directly, company visits, Devotion On Society (P2M), mentoring religion to instill religious application in their activities and internships in the company for 3 months. This is consistent with the objectives of the national education. To achieve a fair society, and prosperous in order to reduce the unemployment of educated graduate. To describe the application of the concept of education $2+1$ with the formation of the professionalism then conducted research at the graduate Polytechnic LP3I Bandung year of 2011 who graduated in 2014. In particular, the satisfaction of graduates in getting a job, appropriate expertise and ability divisions Career and Placement $(\mathrm{C} \& \mathrm{P})$ to assist in the alumni work.

\subsection{Focus}

Soft skills and hard skills of graduates (exit study) Polytechnic LP3I Bandung year 2011.

\subsection{Problem Formulation}

1. How is the alumni satisfaction in getting a job?

2. Is the work of alumni relevant to their expertise?

3. How is the division of C \& C's ability to help the 
alumni work?

\subsection{Research Objectives}

To determine the image:

1. Satisfaction graduates in getting a job

2. The work of alumni get relevant to their expertise

3. Ability division of $\mathrm{C} \& \mathrm{P}$ in placing its graduates work

\subsection{Study of Theory}

1. Quality of Education As revealed E. Mulyasa (2009; 5) Improving the quality of education is also influenced by: "Completion of systemic to all educational components such as: improving the quality and equity of distribution of teachers, enhanced curriculum, learning resources, educational facilities are adequate, supportive learning environment and supported by government policy / political will, both at the central and regional levels" . According to Benjamin Bloom in Nana Sudjana (2009: 46) that: educational goals we want to achieve is classified into three areas, namely cognitive, affective and psychomotor". a. Cognitive field; namely learning through discrimination, concepts and rules. Learning discrimination, the ability to distinguish between objects based on the characteristics of certain case. The ability influenced by maturity, growth and education.Learning concept, namely the ability to place objects that have the same characteristics into one group / particular classification. The concept expressed in the form of language symbols. Learning the rules in effect produce some symbols concept. Learning rules through both oral and written language.

b. Affective field; that attitude is the readiness and willingness of a person to accept or reject an object based on an assessment of the object or the tendency of people to behave. Study results appear in the form of a willingness attitude, interest, attention, feelings change and others. Attitudes can be learned and changed through the learning process. c. Psychomotor field; that is associated with the ability to use the movement of the limbs so as to have a regular series of movement sequences, flexible, precise, fast and smoothly.

\section{Curriculum}

The definition of the curriculum, according to experts on www.academia.edu:

The curriculum is designed instruction or number of subjects systematically arranged for adjusting kind of program to obtain a diploma. (Crow and Crow)

The curriculum is a systematic teaching group or sequence of subjects required for graduation or certification in major subjects, such as social learning curriculum, physical education curriculum (Carter V. Good in Oliva, 191: 6)

The curriculum is the whole experience of students under the guidance of teachers (Hollis L. Caswell and Doak S. Campbell in Oliva, 1991: 6)

The curriculum is as a plan to improve the learning set for someone to educate (J. Galen Saylor, William M. Alexander, and Arthur J. Lewis in Oliva 1991: 6)

The curriculum is a systematic teaching group or sequence of subjects required for graduation or certification in major subjects, such as social learning curriculum, physical education curriculum (Carter V. Good in Oliva, 191: 6)

Conclusion: The curriculum is learning plans for students and teaching for teachers to be educated person.

\section{Professionalism}

Definition of professionalism by Longman (1987) in wikipedia.org: "The properties (ability, skill, how the implementation of something and others) as reasonably contained in or done by a professional" Definition of professionalism according to KBBI (1994) in wikipedia.org: [1] Professionalism comes from profession were significantly associated with profession and require 
a special skill for running, (KBBI, 1994). So, professionalism is behavior, expertise or the qualities of a professional person.

\section{Work Competency}

According to Alain Mitrani, murray and Davis in Competency based Human resource management, quoted from thesis.binus.ac.id, means an individual characteristic who usually related with effective performance and be the best.

Spencer \& Mc. Clelland categorized the competency become three factors, they are: knowledge, skill and personal characteristic:

1. knowledge from facts and procedure

2. The managerial skill, such as: develop other person, team work and so on.

3. Personal characteristic, such as: adjusted skill, self confidence, toleranceto the stress, integrity and so on.

\section{Research Methods}

This study used a qualitative descriptive method because the problem is complex, dynamic and full meaning. The instrument used of data is purposive sampling questioner. The data of student graduation year 2011 who graduated in 2014. Meanwhile, who completed a questionnaire and were valid as many as 159 alumni. Consisting of Business Administration Prodi totaling 44 people, Information Management department of 43 people, accounting department of 54 people and as many as 18 people . Analysis of Public Relations department of the data through domain analysis (Polytechnic Alumni LP3I Bandung), taxonomy (class of 2011), komponensial (data valid) and themes (the alumni satisfaction, job suitability and placement process division $\mathrm{C} \& \mathrm{P}$ ). Test the credibility of the data with observations during the process before working with the data clearly, discussions with team $\mathrm{C} \& \mathrm{P}$ and the analysis of the case.

\section{Results and Discussion Research Result}

1. Satisfaction graduates in getting a job a. Study Program of Business Administration Statement of alumni, they are very satisfied or not to the benefit of science in favor of a career can be divided as follows: Stating Very Dissatisfied (STP) no (0\%), Not Satisfied (TP) for 2 people (3\%), Self-Satisfied (CP) as many as 15 people (34\%), Satisfied (P) as many as 23 people (52\%), and which states Very Satisfied (SP) by 5 people (11\%).

Based on the results of the questionnaire above, the benefit of science in study program Business Administration Alumni stated satisfied . the perception of graduates to benefit science in support of the career is quite good.

\section{b. Information Management Program}

Statement of alumni, they are very satisfied or not to the benefit of science in favor of a career can be divided into:

STP stating no (0\%), TP as much as 2 people (4.65\%), CP as many as 14 people (32.6\%), $\mathrm{P}$ as many as 26 people $(60.5 \%)$, and the states of SP by 1 person (of $0.02 \%$ ) .

Based on the results of the questionnaire above, the benefit of science graduates study program stated satisfied. The perception of Information Management graduates to benefit science in support of the career is quite good.

\section{c. Accounting}

Statement of alumni, they are very satisfied or not to the benefit of science in favor of a career can be divided into: STP stating no (0\%), TP as much as 2 people $(3.70 \%), \mathrm{CP}$ as many as 20 people $(37.03 \%), \mathrm{P}$ as many as 26 people $(48.14 \%)$, and are expressed SP they arej 6 people $(11,11 \%)$. 
Based on the results of the questionnaire above, the benefit of science graduates expressed satisfied. The perception of Accounting Department Alumni to benefit science in support of the career is quite good.

\section{d. Public Relations}

According to the alumni of satisfaction in getting a job as follows: STP stating no (0\%), TP as much as 4 people (22.22\%), CP by 5 people (27.78\%), P by 5 people (27.78\%, and the states of SP by 4 people ( $22.22 \%$ ).

Based on the results of the above questionnaire, suitability Alumni Relations most study program stated quite satisfied and satisfied . the perception of alumnus of the appropriateness of work is quite good.

2. The work of alumni that is relevant to their expertise

\section{a. Business Administration}

According to the alumni of satisfaction in getting a job as follows. STP stating no (0\%), TP as much as 4 people (9\%), CP by 22 people (50\%), $\mathrm{P}$ as many as 15 people (34\%), and the states of SP by 3 people $(7 \%)$.

Based on the results of the questionnaire above, the suitability of Business Administration Alumni most states quite satisfied, namely: 50\%. Perception of alumni to work is quite good.

b. Informatics

Management

According to the alumni of satisfaction in getting a job as follows. STP stating no (0\%), TP as much as 4 people $(20.93 \%), \mathrm{CP}$ as many as 14 people (32.56\%), $\mathrm{P}$ as many as 15 people (34.88\%), and the states of SP by 5 people (11.63\%).

Based on the results of the questionnaire above, the suitability of Management Alumni study program stated satisfied the perception of most graduates for suitability work is quite good.

\section{c. Accounting}

According to the alumni of satisfaction in getting a job as follows. Which states STP by 2 people (3.70\%), TP of 7 people $(12.70 \%), \mathrm{CP}$ as many as 18 people $(33.33 \%), \mathrm{P}$ as many as 17 people $(31.48 \%)$, and the states of SP as 10orang (18.52\%).

Based on the results of the above questionnaire, suitability Accounting Department Alumni most states quite satisfied .The perception of alumnus of the appropriateness of work is quite good.

\section{d. Public Relations}

Statement of alumni, they are very satisfied or not to the benefit of science in favor of a career can be divided into: It states very dissatisfied (STP) no $(0 \%)$, not satisfied (TP) no (0\%), fairly satisfied (CP) of 8 people (44.44\%), satisfied (P) 8 people ( $44.44 \%$ ), and which states very satisfied (SP) for 2 persons

$(11.11 \%)$.

Based on the results of the questionnaire above, the benefit of science graduates study program stated satisfied. The perception of Alumni Relations for the benefit of science in support of the career is quite good.

3. Ability division of $\mathrm{C} \& \mathrm{P}$ in assisting alumni

\section{a. Business Administration}

According to the alumni of satisfaction in getting a job as follows. Which states STP by 2 people (4.55\%), TP $3(6.82 \%), \mathrm{CP}$ as many as 16 people (36.36\%), $\mathrm{P}$ as many as 15 people (34.09\%), and are expressed SP as 8 people (18.18\%). Based on the results of the above questionnaire, mostly Administration Alumni study program stated quite satisfied with the work placement. Thus, the perception of alumni positive rate against the placement of employment opportunities are performed by LP3I to alumni.

\section{b. Informatics Management}

According to the alumni of satisfaction in getting a 
job as follows. STP stating no (0\%), TP of 8 people (18.60\%), CP sebanyak16 (18\%), P as many as 18 people $(41.86 \%)$, and the states of SP by 1 person (2.33

$\%)$.

Based on the results of the above questionnaire, alumni of Information Management study program , most of them they are satisfied with the placement, the positive perception of the placement of alumni assess the work done by LP3I to alumni.

\section{c. Accounting}

According to the alumni of satisfaction in getting a job as follows. STP stating no (0\%), TP 4 (7.41\%), $\mathrm{CP}$ as many as 13 people (24.07\%), $\mathrm{P}$ as many as 25 people $(46.29 \%)$, and are expressed SP as many as 12 people (22,22). Based on the results of the above questionnaire, mostly Administration Alumni program study expressed his satisfaction on working field. So placement, a positive perception of the placement of alumni assess the work done by LP3I to alumni.

d.

Public

Relations

According to the alumni of satisfaction in getting a job as follows. STP stating no (0\%), TP 1 (5.56\%), the $\mathrm{CP}$ of 8 people (44.40\%), $\mathrm{P}$ as many as 6 people $(33.30 \%)$, and the states of SP were 3 people ( $16.70 \%)$.

Based on the results of the above questionnaire, Alumni Relations most Program study stated quite satisfied with the placement work .So, a positive perception of the placement of alumni assess the work done by the Polytechnic LP3I Bandung to alumni.

\section{Discussion}

1. Satisfaction graduates in getting a job:

a. Department of business administration 2\% satisfied

b. Management department of informatics $60.5 \%$ satisfied

c. $48.14 \%$ satisfied Accounting Department d. Department of PR $27.78 \%$ fairly satisfied Alumni to get job satisfaction showed professionalism alumni who considered good. That is applicable curriculum is in conformity with the needs of the business. Behavioral study of the cognitive, affective and psychomotor appropriate guidance / expectations of teachers and students themselves as alumni. Or in other words have the ability to work according to the company's expectations.

2. The work of alumni get relevant to their expertise

a. Department of business administration 50\% satisfied

b. Management department of informatics $34.88 \%$ satisfied

c. $33.33 \%$ satisfied Accounting Department d. Department of PR $44.44 \%$ fairly satisfied

Alumni feel quite appropriate work areas of expertise, competence means to have sufficient performance / effective. It is seen that graduates have the technical knowledge, managerial teamwork, have personally can adapt, confidence and integrity.

3. Ability division of $\mathrm{C} \& \mathrm{P}$ in helping the working process alumni

a. Department of business administration $36.36 \%$ somewhat satisfied

b. Management department of informatics $41.86 \%$ satisfied

c. $46.29 \%$ satisfied Accounting Department d. Department of PR $44.40 \%$ fairly satisfied

Level of alumni satisfaction assisted work process division $\mathrm{C} \& \mathrm{P}$ is quite, meaning by providing the knowledge and skills beyond the existing curriculum, making it easy to put its graduates, but some chose looking for a job based on their own business.

\section{Conclusion}

1. Satisfaction graduates in getting a job relatively satisfied, meaning that they get the job as expected, and vice versa with the satisfaction of the company in their recruitment. Has formed professionalism at Polytechnic LP3I Bandung graduates. 
2. Work gained quite relevant to their expertise, meaning that the alumni have sufficient competence to perform the work. Soul professionalism in the mastery of competencies possessed enough alumni. 3. Ability division of $\mathrm{C} \& \mathrm{C}$ in the working process alumni rated enough, some more confidence to get the job their own business. This means that the concept of education $2+1$ enough to equip graduates in the work.

\section{Bibliography}

E. Mulyasa. 2008, Cet. All 3.Standar Competency and Certification Guru.PT. Teens Rosda paper. Duo

Prof. Dr. Sugiono, 2013, Cet. Ke-4, Metode

Penelitian Kombinasi (Mixed Methods), Alfabeta, Bandung.

Www.thesis.binus.ac.id

www.wikipedia.org

www.academia.ed 